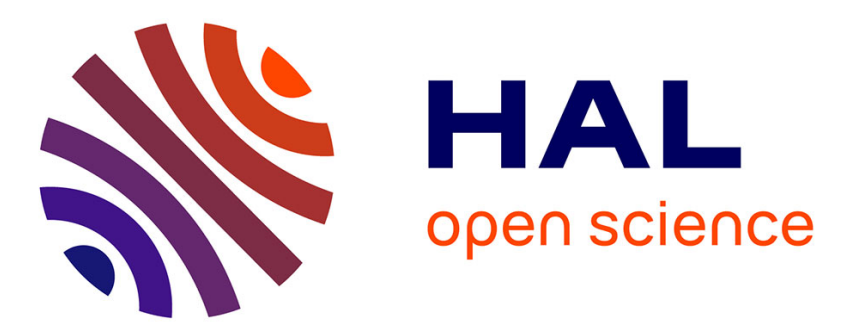

\title{
Power Control of Wind Generator Using PI Regulator
} Manale Bouderbala, Badre Bossoufi, Ahmed Lagrioui, Mohammed Taoussi, Hala Alami Aroussi, Yasmine Ihedrane

\section{To cite this version:}

Manale Bouderbala, Badre Bossoufi, Ahmed Lagrioui, Mohammed Taoussi, Hala Alami Aroussi, et al.. Power Control of Wind Generator Using PI Regulator. nternational Meeting on Advanced Technologies in Energy and Electrical Engineering, Nov 2018, Fez, Morocco. hal-01941404

\section{HAL Id: hal-01941404 \\ https://hal.science/hal-01941404}

Submitted on 1 Dec 2018

HAL is a multi-disciplinary open access archive for the deposit and dissemination of scientific research documents, whether they are published or not. The documents may come from teaching and research institutions in France or abroad, or from public or private research centers.
L'archive ouverte pluridisciplinaire HAL, est destinée au dépôt et à la diffusion de documents scientifiques de niveau recherche, publiés ou non, émanant des établissements d'enseignement et de recherche français ou étrangers, des laboratoires publics ou privés. 
IMAT3E' 18

International Meeting on Advanced Technologies in Energy and Electrical

Engineering

\section{Power Control of Wind Generator Using PI Regulator \\ ${ }^{1 *}$ BOUDERBALA Manale, ${ }^{1,2}$ BOSSOUFI Badre, ${ }^{3}$ LAGRIOUI Ahmed, ${ }^{2}$ TAOUSSI Mohammed, ${ }^{1}$ ALAMI AROUSSI Hala, ${ }^{2}$ IHEDRANE Yasmine.}

*Bouderbala.manale@gmail.com

'Laboratory of Electrical Engineering and Maintenance, Higher School of Technology, Oujda, Morocco

${ }^{2}$ LISTA Laboratory, Faculty of Sciences Dhar El Mahraz, Sidi Mohammed Ben Abdellah University Fez - Morocco

${ }^{3}$ Department of Electrical and Computer Engineering the Higher National School of Arts and Trades, Moulay Ismail University Meknes, Morocco

Recently, the wind power represents an important potential. In order to exploit this potential efficiently, the wind turbine must operate at different speeds when the wind speed changes. To deal with that, this study presents essentially the modeling and power control of Wind Energy Conversion Systems (WECS) based on Doubly Fed Induction Generator (DFIG) by using the vector control, this later relies on PI regulator [1]. Firstly, the model of the wind energy conversion systems is shown. Then, the control system is applied to ensure that our objective is achieved. This control consists of two parts: the first is to maximize the energy extracted from the turbine using the MPPT strategy (Maximum Power Point Tracking), the second part is to control the DFIG's power using the PI regulator. Finally, the results will be presented in Matlab/Simulink environment.

The WECS process transforms wind energy into mechanical energy by the turbine and, into electrical energy by the generator. It consists of wind, turbine, multiplier and generator [2]. The following diagram illustrates the modeling of the WECS:

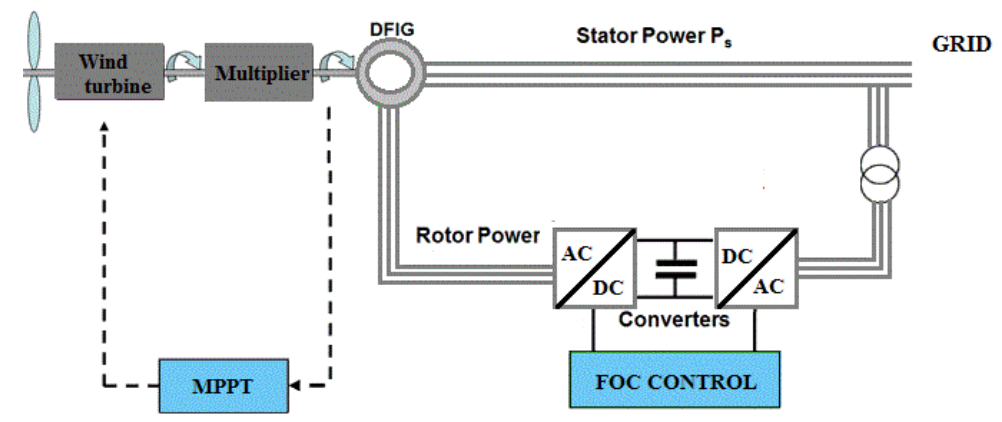

Figure 1: WECS model 
IMAT3E' 18

\section{International Meeting on Advanced Technologies in Energy and Electrical Engineering}

The MPPT control is used to extract the maximum power. It is based on the adjustment of the turbine rotation speed that allows the maximum power to be extracted [3].

Field-oriented control (FOC) is a technique for controlling AC electrical machines, based on the DC machine principle, which is characterized by a natural decoupling between flux and currents, in order to simplify the control of the machines [4]. This control consists of aligning the flux of the rotor (or stator) on one axis of the Park reference. In our case, we orient the flux along the axis d.

So we have : $\quad \varphi s q=0$ and $\varphi s d=\varphi s$

After the orientation of the fluxes, the expressions below are showing the relationship between the currents and the rotor voltages that will be applied:

$$
\begin{aligned}
& V r d=\operatorname{Rr} \cdot \operatorname{Ird}+\left(\operatorname{Lr}-\frac{M^{2}}{L s}\right) \cdot \frac{\mathrm{dIrd}}{\mathrm{dt}}-\mathrm{g} \cdot \omega s \cdot\left(\operatorname{Lr}-\frac{M^{\mathrm{2}}}{L s}\right) \cdot \operatorname{Iqr} \\
& V r q=\operatorname{Rr} \cdot \operatorname{Irq}+\left(\operatorname{Lr}-\frac{M^{2}}{L s}\right) \cdot \frac{\mathrm{d} \operatorname{Irq}}{\mathrm{dt}}+\mathrm{g} \cdot \omega \mathrm{s} \cdot\left(\operatorname{Lr}-\frac{M^{2}}{L s}\right) \cdot \operatorname{Idr}+\mathrm{g} \cdot \omega \mathrm{s} \cdot \frac{M \cdot V s}{L s \cdot \omega s}
\end{aligned}
$$

The expressions of the powers are expressed as follows:

$$
\begin{gathered}
P s=-\frac{V s \cdot M}{L s} \cdot \operatorname{Irq} \\
Q s=\frac{V s^{2}}{L s \cdot \omega s}-\frac{V s \cdot M}{L s} \operatorname{Ird}
\end{gathered}
$$

In order to control the machine powers, this command acts directly on the voltages by applying a PI regulator on each axis and neglecting the coupling terms between the two axes.

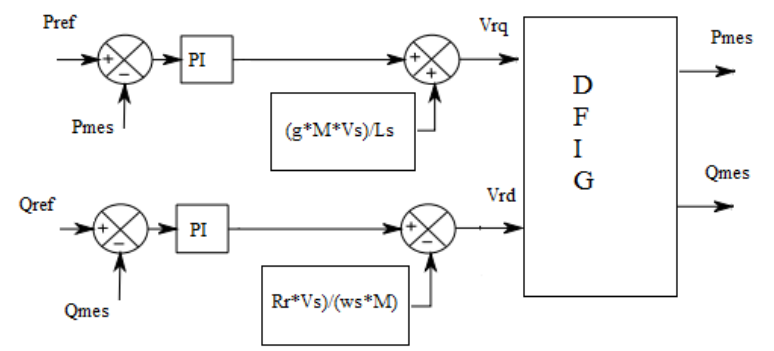

Figure 2: Direct Control of active and reactive powers of DFIG

The WECS is validated using the software Matlab / Simulink, to prove the efficiency of the vector control. So, we will apply a wind profil (fig.3). From the fig.4 and fig.5, we notice that the stator powers follow the setpoint during all the variations of the random wind speed. Moreover, the fig. 6 shows that the stator currents have sinusoidal shape without harmonics. 
IMAT3E' 18

International Meeting on Advanced Technologies in Energy and Electrical

Engineering

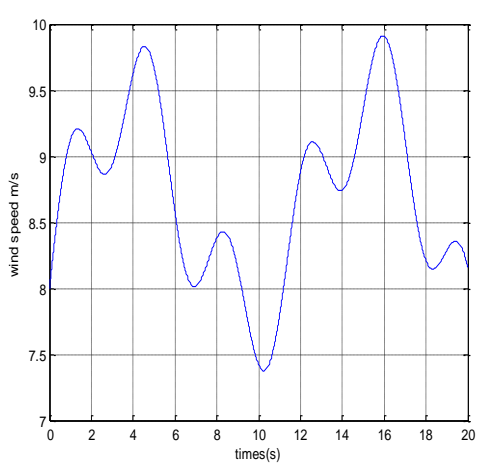

Figure 3: Wind $\operatorname{Speed}(\mathrm{m} / \mathrm{s})$

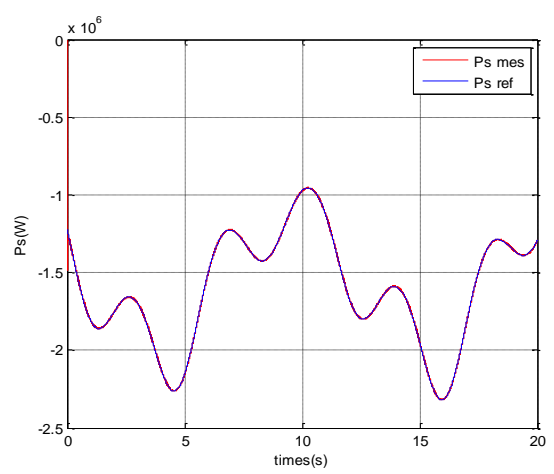

Figure 4: Stator Active Power(W)

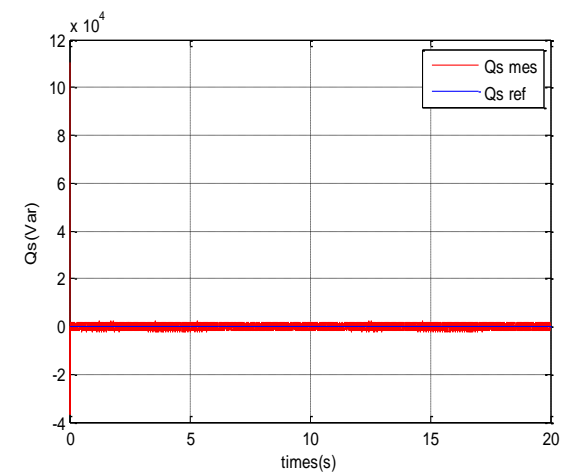

Figure 5: Stator Reactive Power(Var)
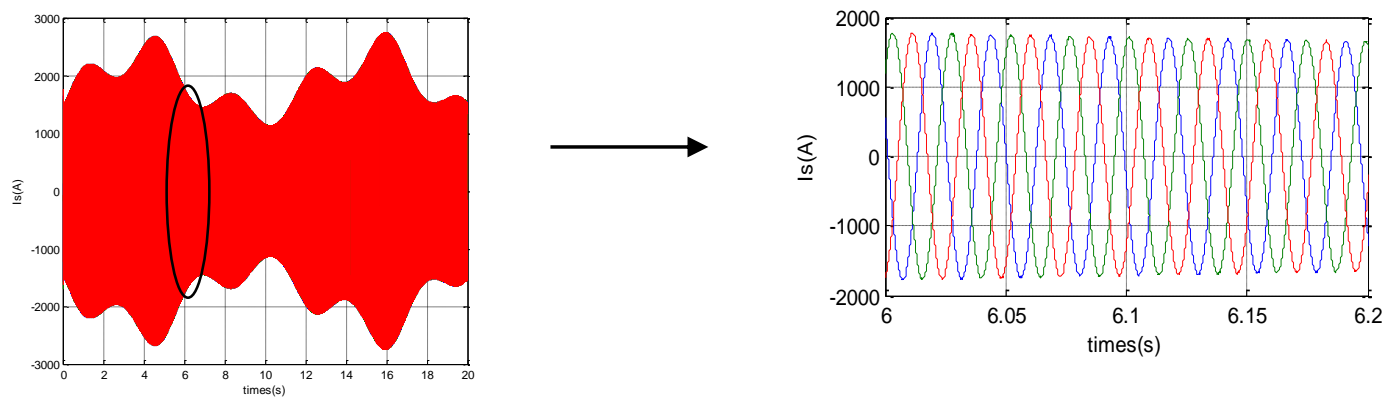

Figure 6: Stator currents(A)

We conclude that, the FOC control combined to the MPPT strategy is simple to implement, give good results and allows controlling the active and reactive powers easily.

\section{References}

1. T. Ackermann and Soder, L. " An Overview of Wind Energy-Status 2002 ", Renewable and Sustainable Energy Reviews, 6(1-2), 67-127 (2002)

2. B.bossoufi, m.karim, a.lagrioui, m.taoussi, m. El ghamrasni "Backstepping Adaptive Control of DFIG-Generators for VariableSpeed Wind Turbines" IJCT International Journal of Computers \& Technology, pp3719-3733, Vol.12 No.7, February 2014.

3. H.Alami, E.Ziani, B.Bossoufi, "Speed control of the doubly fed induction generator applied to a wind system" Journal of Theoretical and Applied Information Technology, pp426-433, Vol.83 No.3, January 2016

4. M. Taoussi, M. Karim, D. Hammoumi, C. Elbakkali, B. Bossoufi, N. El Ouanjli,"Comparative study between Backstepping adaptive and Field-oriented control of the DFIG applied to wind turbines", $3^{\text {rd }}$ IEEE International Conference on Advanced Technologies for Signal and Image Processing, May 2017 